\title{
Genetic modulation of the serotonergic pathway: influence on weight reduction and weight maintenance
}

\author{
Dirk Wallmeier · Julia K. Winkler · Thomas Fleming • Annika Woehning • \\ Katharina Huennemeyer $\cdot$ Eva Roeder $\cdot$ Peter P. Nawroth $\cdot$ Hans-Christoph Friederich \\ Christian Wolfrum · Jobst-Hendrik Schultz • Gottfried Rudofsky
}

Received: 4 February 2013/Accepted: 7 June 2013/Published online: 25 June 2013

(C) Springer-Verlag Berlin Heidelberg 2013

\begin{abstract}
The serotonergic pathway plays a major role in the development of obesity. Its activity can be modulated by the 5 -HT transporter-linked polymorphic region in the SLC6A4 gene and the upstream variable number of tandem repeats polymorphism in the MAOA gene. We studied whether these genetic modulations have an influence on weight reduction and weight maintenance in a one-year weight reduction program (OPTIFAST ${ }^{\circledR} 52$ ). The polymorphisms were genotyped by PCR in a sample of 135 female and 67 male subjects with severe obesity $(44 \pm$ 13 years, $122.3 \pm 22.2 \mathrm{~kg}$, BMI: $41.7 \pm 6.7 \mathrm{~kg} / \mathrm{m}^{2}$ ). The program leads to a total weight loss of $19.9 \pm 9.8 \mathrm{~kg}$ $(16.9 \pm 8.3 \%)$ in women and $27.4 \pm 13.6 \mathrm{~kg}(20.4 \pm$ $9.9 \%)$ in men. Anthropometric measurements and blood levels were determined at the start of the program (T0), after the weight reduction phase (T1) and after the subsequent weight maintenance phase at the end of the
\end{abstract}

Jobst-Hendrik Schultz and Gottfried Rudofsky contributed equally to this work.

D. Wallmeier · J. K. Winkler · T. Fleming · A. Woehning ·

P. P. Nawroth · G. Rudofsky ( $\square)$

Department of Medicine I and Clinical Chemistry,

University of Heidelberg, Im Neuenheimer Feld 410,

69120 Heidelberg, Germany

e-mail: grudofsky@yahoo.de

K. Huennemeyer · H.-C. Friederich · J.-H. Schultz

Department of Psychosomatic and General Internal Medicine,

University of Heidelberg, Im Neuenheimer Feld 410,

69120 Heidelberg, Germany

E. Roeder $\cdot$ C. Wolfrum

Institute of Food Nutrition and Health, Swiss Federal Institute of Technology, ETH Zürich, SLA C94, Schorenstraße 16, 8603 Schwerzenbach, Switzerland program (T2). Each polymorphism alone did not significantly influence weight loss or weight maintenance neither in men nor in women. However, women carrying both risk genotypes (SS and 3/3) displayed a lower total weight loss during the program $(p=0.05)$. This effect derived mainly from difficulties in the weight maintenance phase $(p=0.11)$, while the weight reduction phase was not affected $(p=0.61)$. No influence was found in men $(p=0.93)$. Modulation of the serotonergic pathway by carrying both risk alleles seems to influence success of weight loss programs in women with severe obesity due to problems in stabilizing body weight after weight reduction.

Keywords Weight maintenance $\cdot$ Weight regain $\cdot$ Weight loss $\cdot$ Obesity $\cdot 5$-HTTPLR $\cdot$ MAOA uVNTR $\cdot$ SLC6A4

\section{Introduction}

Obesity is one of the most serious health problems in our society (York et al. 2004). It is characterized by an excessive accumulation of body fat and is defined as a BMI of $\geq 30 \mathrm{~kg} / \mathrm{m}^{2}$. Obesity is associated with a variety of diseases including hypertension, type 2 diabetes and coronary heart disease (Kopelman 2000; Bombelli et al. 2011). Individual lifestyle factors, such as eating habits or physical activity, are major contributors to the development of obesity (Ogden et al. 2007). However, various genetic and neurobiological factors are also acknowledged to impact on the pathogenesis of obesity (Brooks et al. 2013; Need et al. 2006; Bray 2006; Rankinen et al. 2006; Winkler et al. 2012; Woehning et al. 2012).

Serotonin (5-hydroxytryptamine, 5-HT) is known to influence the neuroendocrine functions, sleep, libido and 
body weight regulation (Leibowitz and Alexander 1998). It has been observed that female subjects diagnosed with binge eating or bulimia have reduced central nervous 5-HT activity (Kuikka et al. 2001; Tauscher et al. 2001)

5-HT is regulated, in part, by the serotonin transporter (5-HTT or SERT), which transports released 5-HT from the synaptic cleft back to the nerve terminal (Smeraldi et al. 2006). In the nerve terminal, serotonin is degraded by monoamine oxidase A (MAOA) which also degrades dopamine and norepinephrine. This pathway is influenced by polymorphisms in the promoter regions of both the 5-HTT and MAOA. Human 5-HTT is encoded by the solute carrier family 6, member 4 (SLC6A4) gene, which is located on chromosome 17q11.2 and is composed of 14 exons (Lesch et al. 1994). 5-HTTLPR is a 44-bp insertion/deletion polymorphism leading to either a short (S) or long (L) variant (Lesch et al. 1993). It has been demonstrated that the $\mathrm{S}$ allele is associated with a $40 \%$ decrease in transcriptional activity in vitro (Heils et al. 1996; Lesch et al. 1996; Hranilovic et al. 2004) and is associated with anxiety, affective disorder, diabetes and obesity in both human and animal studies (Sookoian et al. 2007; Lesch et al. 1996; Collier et al. 1996; Pluess et al. 2010). Furthermore, this polymorphism has also been shown to be associated with nutritional impairment in female patients suffering from bulimia nervosa (Monteleone et al. 2006).

In contrast, the human MAOA gene is located on chromosome Xp11.23 and consists of 15 exons (Sabol et al. 1998). The transcriptional activity of the MAOA promoter is influenced by an upstream variable number of tandem repeats (uVNTR). The most common repeats $(\mathrm{R})$ are the twofold, threefold, 3.5-fold, fourfold and fivefold (Sabol et al. 1998). The presence of $3.5 \mathrm{R}$ and $4 \mathrm{R}$ alleles has been shown to lead to two- to tenfold greater transcription activity than either the 2R or 3R (Deckert et al. 1999; Sabol et al. 1998). Studies have shown that the low-activity alleles are related to obesity and psychiatric disorders and may therefore influence the ability to reduce and maintain weight reduction in people who are prone to develop obesity (Need et al. 2006; York et al. 2004; Beach et al. 2010). The association of $5 \mathrm{R}$ allele with respect to obesity and weight regulation remains unclear (Pluess et al. 2010; Collier et al. 1996).

In this study, we have analyzed the 5-HTTLPR and the MAOA uVNTR polymorphism in 202 subjects with obesity undergoing a two-staged weight reduction program consisting of 12-week weight reduction period followed by 40-week weight maintenance period. It is hypothesized that the presence of polymorphisms in the 5-HTT and MAOA genes is associated with an impaired outcome of weight reduction and/or maintenance.

\section{Materials and methods}

The weight reduction program OPTIFAST ${ }^{\circledR} 52$

All study participants were selected from the OPTIFAST $^{\circledR} 52$ program (franchise holder Nestlé Inc., Switzerland) at the University Hospital of Heidelberg. This program is a 52-week lifestyle intervention which involves weekly group meetings and is under the supervision of doctors, nutritional advisers, psychologists and physiotherapists. The participants are $\geq 18$ years of age and have a BMI $\geq 30 \mathrm{~kg} / \mathrm{m}^{2}$. The program is divided into four stages: (1) 1-week introduction; (2) 12-week active weight loss period with low-calorie formula diet $(800 \mathrm{kcal})$ consisting of five protein shakes per day as meal replacements; (3) 6-week transition period in which the formula diet is slowly replaced by self-prepared low-calorie food and (4) 33-week long-term weight management period in which the participants are instructed in finding their optimal calorie intake for weight stabilization. All periods are supported by medical examinations, exercise sessions, behavior therapy and education on nutritional guidance.

For the purpose of this study, the described program was divided into two major phases: (1) the weight reduction phase, i.e., data from the beginning (T0) and after the weight reduction stage at 12 (T1), and the weight maintenance phase, i.e., data from $\mathrm{T} 1$ until the end of the program at 52-weeks.

\section{Study population}

This study involved 202 individuals with obesity who attended the OPTIFAST ${ }^{\circledR} 52$ program at the University Hospital of Heidelberg between 2005 and 2010. A total of 135 women and 67 men aged between 18 and 72 years (mean age $44.4 \pm 12.5$ years) were involved in the study. Mean body weight at the beginning of the program (T0) was $122.3 \pm 22.2 \mathrm{~kg}$ resulting in a mean BMI of $41.7 \pm 6.7 \mathrm{~kg} / \mathrm{m}^{2}$. From 202 participants, $135(66.8 \%)$ completed the program. The attrition rate was $33.2 \%$; 39 participants stated that this was due to the high financial cost for enrolling and attending the OPTIFAST ${ }^{\circledR} 52$ program. Other reasons, given by 14 participants, included business-related factors, e.g., movement out of the Heidelberg areas due to a new job, low of employment or altered working schedule. Four participants became pregnant during the program, and eight left without stating any reason for early termination.

Anthropometrical and laboratory measurements

Fasting blood samples were collected at T0, T1 and T2. Blood glucose, total cholesterol, low density lipoprotein 
(LDL), high density lipoprotein (HDL) and triacylglycerols were measured in the central laboratory of the University Hospital of Heidelberg. Weight and height were assessed using standard methods and BMI was calculated as weight in kilograms $(\mathrm{kg})$ divided by the square of the height in meters (m). Information regarding medical history, eating behavior and lifestyle factors was gathered using a standardized questionnaire provided by the manufacturer (Nestlé Inc., Switzerland).

\section{Genotyping}

Genomic DNA was isolated from $250 \mu \mathrm{l}$ EDTA anticoagulated whole blood using the peqGOLD Blood DNA Mini Kit (PEQLAB Biotechnologie GmbH, Erlangen, Germany). Genotyping was performed using the polymerase chain reaction (PCR).

\section{5-HTTLPR polymorphism}

The reaction tube had a final volume of $50 \mu \mathrm{l}$ which contained $32.75 \mu \mathrm{l}$ distilled water, $10 \mu \mathrm{l}$ Green GoTaq ${ }^{\circledR}$ Flexi Buffer, $3 \mu \mathrm{l} \mathrm{MgCl}_{2}, 1 \mu \mathrm{l}$ dNTPs (Fermentas $\mathrm{GmbH}$, St. Leon-Rot, Germany), $1 \mu$ forward (5'-GTTTTGTGTT GCCCTTGCCTAT- $3^{\prime}$ ) and $1 \mu$ reverse $\left(5^{\prime}\right.$-CACCGCCCC TTGTACTTG-3') oligonucleotid primers (Eurofins MWG Synthesis GmbH, Ebersberg, Germany), $0.25 \mu$ GoTaq $^{\circledR}$ Flexi DNA Polymerase (Promega GmbH, Mannheim, Germany) and $1 \mu$ genomic DNA. The procedure started with an initial denaturation step at $94{ }^{\circ} \mathrm{C}$ for $10 \mathrm{~min}$, followed by 42 cycles of denaturation at $94{ }^{\circ} \mathrm{C}$ for $1 \mathrm{~min}$, annealing at $60{ }^{\circ} \mathrm{C}$ for $1 \mathrm{~min}$, extension at $72{ }^{\circ} \mathrm{C}$ for $1 \mathrm{~min}$ and a final extension step at $72{ }^{\circ} \mathrm{C}$ for $5 \mathrm{~min}$.

For the genotyping, we used a modified protocol of the previously published PCR procedure by Iordanidou et al. (2010).

Polymerase chain reaction products were separated on a $3 \%$ agarose gel and stained with ethidium bromide. The sizes of the two products were $705 \mathrm{bp}$ and $749 \mathrm{bp}$.

\section{MAOA uVNTR polymorphism}

The reaction tube had a final volume of $25 \mu \mathrm{l}$ which contained $14.5 \mu \mathrm{l}$ distilled water, $5 \mu \mathrm{l}$ Green GoTaq ${ }^{\circledR}$ Flexi Buffer, $1.5 \mu \mathrm{l} \mathrm{MgCl}_{2}, 1 \mu \mathrm{l}$ dNTPs (Fermentas $\mathrm{GmbH}$, St. Leon-Rot, Germany), $1 \mu$ forward (5'-ACAGCCTCGC CGTGGAGAA- $3^{\prime}$ ) and $1 \mu \mathrm{l}$ reverse (5'-GAACGGACG CTCCATTCGGA-3') oligonucleotid primers (Eurofins MWG Synthesis GmbH, Ebersberg, Germany), $0.2 \mu \mathrm{l}$ GoTaq ${ }^{\circledR}$ Flexi DNA Polymerase (Promega GmbH, Mannheim, Germany) and $1 \mu$ genomic DNA. The procedure started with an initial denaturing step at $94{ }^{\circ} \mathrm{C}$ for $5 \mathrm{~min}$, followed by 35 cycles of denaturation at $94{ }^{\circ} \mathrm{C}$ for $30 \mathrm{~s}$, annealing at $55^{\circ} \mathrm{C}$ for $30 \mathrm{~s}$, extension at $72{ }^{\circ} \mathrm{C}$ for $30 \mathrm{~s}$ and a final extension step at $72{ }^{\circ} \mathrm{C}$ for $5 \mathrm{~min}$. Primers and PCR procedure were previously published by Lung et al. (2011).

Polymerase chain reaction products were separated on a $2.5 \%$ agarose gel and stained with ethidium bromide. The sizes of the five products were: 2-repeats: $288 \mathrm{bp}$, 3-repeats: $318 \mathrm{bp}, 3.5$-repeats: $333 \mathrm{bp}$, 4-repeats: $348 \mathrm{bp}$ and 5-repeats: $378 \mathrm{bp}$.

On each gel, a negative sample (water) and a Low Range DNA Ladder (Fermentas GmbH, St. Leon-Rot, Germany) were added.

\section{Statistical analysis}

SPSS version 19.0 (SPPS Inc., Chicago, USA) was used for the statistical evaluation. Variables were expressed as mean $\pm \mathrm{SD}$. The $2 \mathrm{R}, 3.5 \mathrm{R}$ and the $5 \mathrm{R}$ variants of the MAOA polymorphism were not included in the analysis due to their low occurrence $(<0.5 \%$ each) as previously reported by Lung et al. (2011). To analyze the 5-HTTLPR polymorphism, we compared the SS genotype to the SL and LL genotype for all subjects and subsequently for each sex separately. This analysis was chosen based on our findings that SL and LL genotype carriers displayed a similar weight course compared to SS genotype carriers, e.g., in female participants weight course in the maintenance phase was $-0.2 \mathrm{~kg}$ in SS genotype carriers versus -2.9 and $-2.0 \mathrm{~kg}$ in SL and LL genotype carriers. This model of analysis was also chosen by Yamakawa et al. (2005).

As the MAOA gene is located on the $\mathrm{X}$ chromosome, no heterogeneous 3/4 genotype is found in men. For the MAOA uVNTR polymorphism, we compared the risk genotype $3 / 3$ to the $3 / 4$ and $4 / 4$ genotype in women and the $3 / 3$ to the $4 / 4$ in men.

The risk group $(\mathrm{R}+)$ comprised the SS genotype of the 5-HTTLPR polymorphism and the $3 / 3$ genotype of the MAOA uVNTR polymorphism. The low-risk genotype group $(\mathrm{R}-)$ was made up by the SL and LL genotype of the 5-HTTLPR polymorphism and the 3/4 and 4/4 genotype of the MAOA uVNTR polymorphism. $\mathrm{R}+$ was compared to the remaining group $\mathrm{R}-$. This low-risk allele group was made up by the $4 / 4$ and 3/4 genotype of the MAOA uVNTR and the LL and SL genotype of the 5-HTTLPR polymorphism. As the MAOA gene is located on the $\mathrm{X}$ chromosome, no heterogeneous 3/4 genotype can be found in men and is therefore not present in the male $\mathrm{R}-$ group. Due to this fact, all results concerning MAOA and risk groups had to be split up according to gender. The Wilcoxon-Mann-Whitney test was used to evaluate differences between the allelic groups. The allelic distribution was determined by the chi-square test $\left(\chi^{2}\right.$-test). $p$ values $\leq 0.05$ were considered as statistically significant. 
A
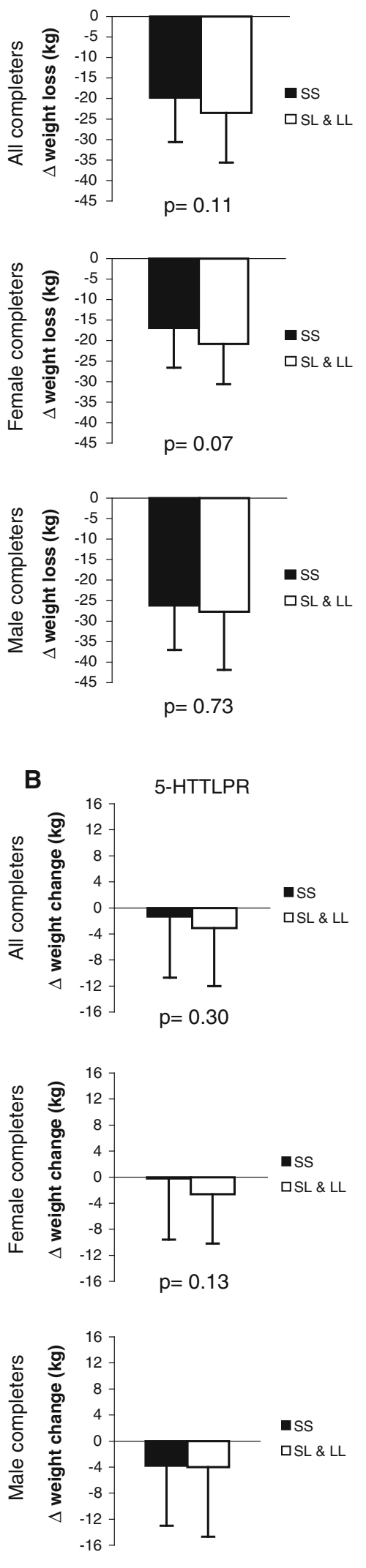

$p=0.82$

SS

$\square S L \& L L$
MAOA UVNTR
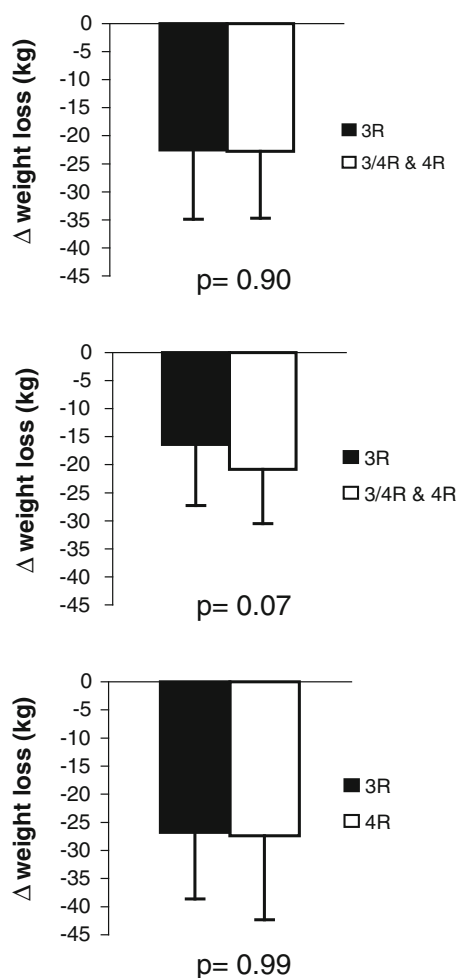

MAOA UVNTR
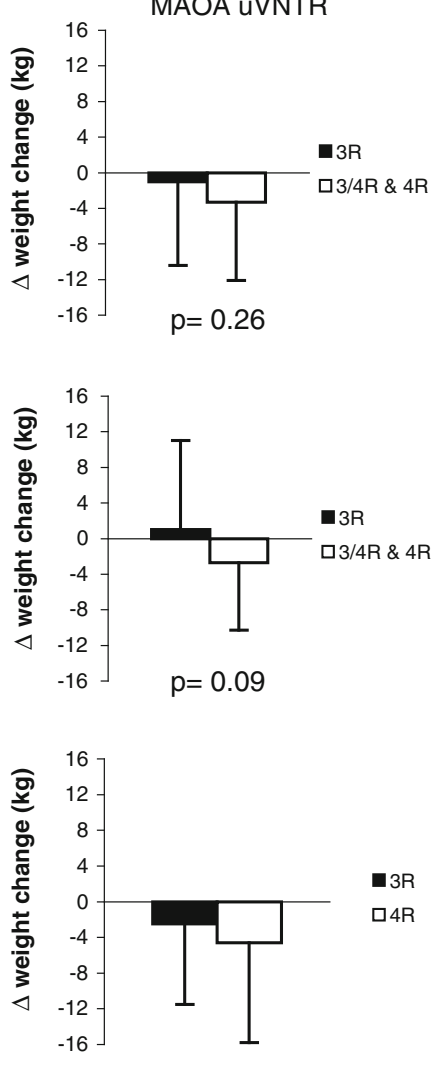

$p=0.75$
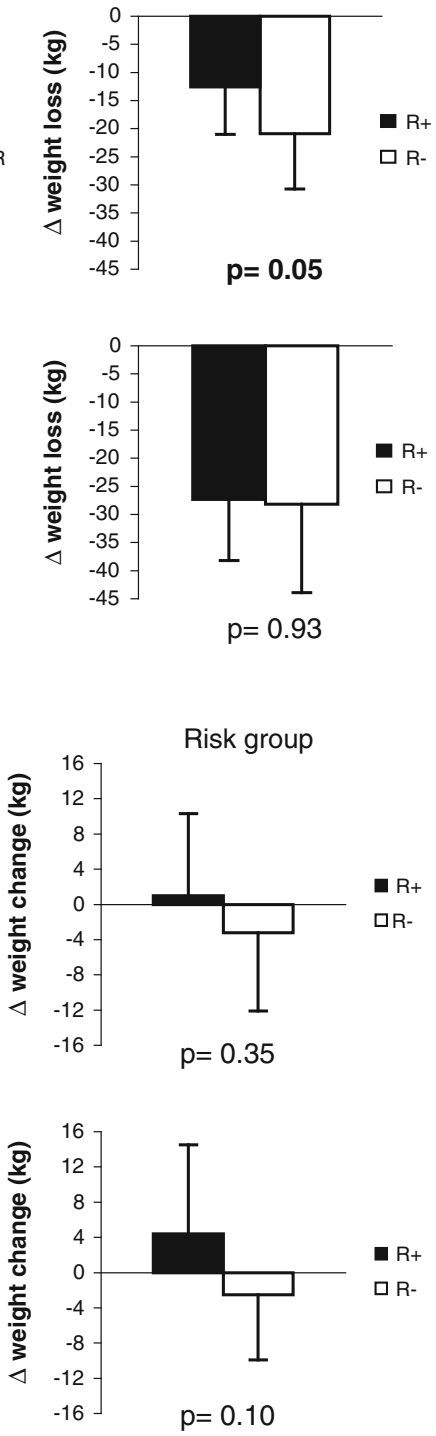

Risk group
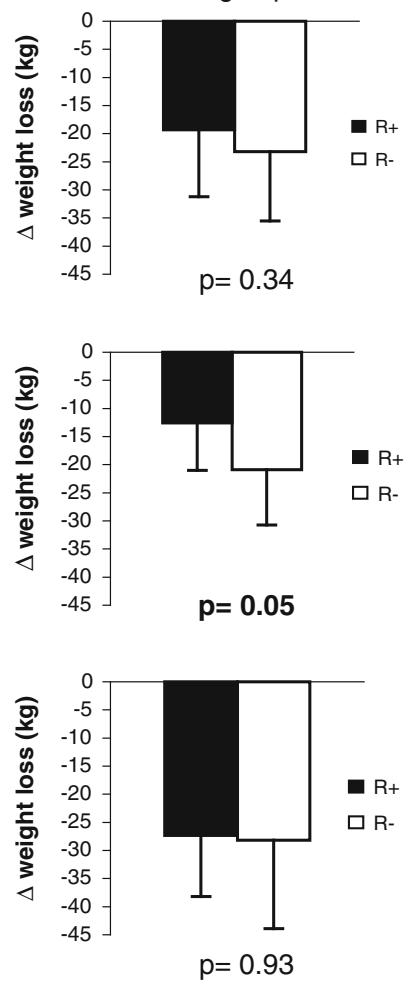

Risk group

$\mathrm{R}+$

R+

- $3 \mathrm{R}$

प4R

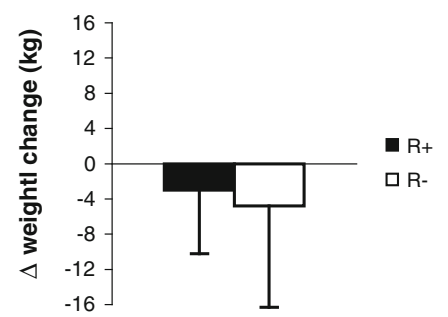

$p=0.90$ 
4Fig. 1 Changes in weight $(\mathrm{kg})$ of all completers according to the 5-HTTLPR polymorphism, the MAOA uVNTR polymorphism and the risk group are given and stratified to gender. Mean values \pm SD and $p$ values are displayed. Significant $p$ values $(p \leq 0.05)$ are standing out in bold. a Total weight loss (T0 $->\mathrm{T} 2)$ of all completers is shown. b Changes in the weight maintenance phase $(\mathrm{T} 1->\mathrm{T} 2)$ are displayed

\section{Results}

This study was performed as a mono-centric longitudinal study, in which 202 non-related Caucasian subjects with severe obesity were analyzed for the 5-HTTLPR polymorphism in the SLC6A4 gene and the uVNTR polymorphism in the MAOA promoter gene.

\section{5-HTTLPR polymorphism}

Genotyping revealed that from a total of 202 subjects, 44 $(21.8 \%)$ carried the SS, $62(30.7 \%)$ the LL and 96 $(47.5 \%)$ the heterogeneous SL genotype. The minor allele frequency of the $\mathrm{S}$ allele was $46 \%$ and allele frequencies were within Hardy-Weinberg equilibrium $(p=0.55)$. A total of $135(66.8 \%)$ subjects completed the program, while $67(33.2 \%)$ terminated early. Further analysis of only those individuals who completed the program showed that at baseline all subjects, men and women with the SS genotype had non-significant lower body weight compared to either the SL and LL genotype carriers (Table 1). Furthermore, the female SS genotype carriers showed a trend for a reduced weight loss (SS: $-16.9 \pm 9.7 \mathrm{~kg}, \mathrm{SL} \& \mathrm{LL}$ : $-20.8 \pm 9.8 \mathrm{~kg}, p=0.07$; Fig. 1a) which was associated with a slightly less effective weight reduction phase (SS: $-16.7 \pm 3.1 \mathrm{~kg}$, SL \& LL: $-18.2 \pm 4.6 \mathrm{~kg}, p=0.18)$ and a less successful weight maintenance phase (SS: $-0.2 \pm 9.4 \mathrm{~kg}, \quad \mathrm{SL} \& \mathrm{LL}:-2.6 \pm 7.5 \mathrm{~kg}, \quad p=0.13$; Fig. 1b).

In men, no differences between the genotypes could be observed (Table 1). No effect on blood pressure, glucose levels or blood lipids was observed in the total population and in both gender groups with respect to the 5-HTTLPR Polymorphism.

\section{MAOA uVNTR polymorphism}

The MAOA gene is located on the $\mathrm{X}$ chromosome; therefore, a heterogeneous 3/4 genotype does not exists in men. As such, we compared the risk genotype $3 / 3$ to the $3 / 4$ and $4 / 4$ genotype in women and the $3 / 3$ to the $4 / 4$ in men. In 131 women, $20(15.3 \%)$ subjects carried the $3 / 3,51$ $(38.9 \%)$ the $4 / 4$ and $60(45.8 \%)$ the heterogeneous $3 / 4$ genotype. The minor allele frequency of the $3 \mathrm{R}$ allele was $38 \%$ and allele frequencies were within Hardy-Weinberg equilibrium $(p=0.74)$. In total, four participants were found to carry either the $2 / 3,2 / 3.5,3 / 3.5$ and $4 / 5$ genotypes and were subsequently excluded from the analysis due to their low occurrence, as has been previously reported (Lung et al. 2011). One participant's results could not be interpreted although genotyping was repeated three times and therefore was also excluded from the analysis. In men, $25(37.9 \%)$ subjects carried the $3 / 3$ and $41(62.1 \%)$ subjects carried the 4/4 genotype.

Further analysis of only those individuals who completed the program showed that body weight at baseline did not vary between the different genotypes for either men ( $p=0.74$ ) or women $(p=0.62)$. For women, the different genotypes did not influence weight loss during the weight reduction phase $(3 / 3:-17.4 \pm 4.8 \mathrm{~kg}, 3 / 4$ and $4 / 4$ : $-18.1 \pm 4.4 \mathrm{~kg}, p=0.54)$. However, female $3 / 3$ carriers were observed to regain weight during the weight maintenance phase compare to the other genotype carriers $(3 / 3$ : $+1 \pm 10 \mathrm{~kg}, 3 / 4$ and 4/4: $-2.7 \pm 7.6 \mathrm{~kg}, p=0.09)$. This had an impact on total weight loss, with a trend for $3 / 3$ carriers to lose less weight (3/3: $-16.4 \pm 10.9 \mathrm{~kg}, 3 / 4$ and 4/4: $-20.8 \pm 9.7 \mathrm{~kg}, p=0.07)$. At the end (T2) of the program, women carrying the $3 / 3$ genotype had a significantly higher BMI compared to either $3 / 4$ and $4 / 4$ genotype group $\left(3 / 3: 37.2 \pm 4.7 \mathrm{~kg} / \mathrm{m}^{2}, 3 / 4 \& 4 / 4: 34.1 \pm\right.$ $6.1 \mathrm{~kg} / \mathrm{m}^{2}, p=0.03$; Table 2). In contrast, no differences could be observed in men. Furthermore, there were no significant differences in blood parameters, blood lipids and blood pressures in either men or in women with respect to the MAOA polymorphism. The drop-out rate was not influenced by the polymorphism (men: $p=0.40$; women: $p=0.40)$.

\section{High-risk group $\mathrm{R}+$}

To establish whether the serotonergic pathway influences weight loss and/or maintenance, participants that carried the risk genotypes for both polymorphism (SS genotype of the 5-HTTLPR polymorphism and 3/3 genotype of the MAOA uVNTR) were grouped together as high-risk $(\mathrm{R}+)$ individuals and compared to the low-risk individuals $(\mathrm{R}-)$ consisting of the LL and SL genotype of the 5-HTTLPR polymorphism and the $4 / 4$ and 3/4 genotype of the MAOA uVNTR.

For female participant, when both polymorphisms are expressed together, a significantly lower total body weight loss was observed $(\mathrm{R}+\mathrm{x}-12.6 \pm 8.4 \mathrm{~kg}, \mathrm{R}-\mathrm{:}-20.9 \pm$ $9.8 \mathrm{~kg}, p=0.05)$. However, the weight reduction phase was not influenced $(\mathrm{R}+\mathrm{:}-16.7 \pm 4.6 \mathrm{~kg}, \mathrm{R}-\mathrm{:}-18.4 \pm$ $4.7 \mathrm{~kg}, p=0.61)$. This effect was mainly caused by a regain of weight in $\mathrm{R}+$ carriers during the weight maintenance phase, whereas the $\mathrm{R}-$ group lost further weight $(\mathrm{R}+: \quad+4.4 \pm 10.1 \mathrm{~kg}, \mathrm{R}-:-2.5 \pm 7.4 \mathrm{~kg}, \quad p=0.11$; Fig. 1b). Therefore, this resulted in a trend for a higher 
Table 1 Baseline characteristics and weight loss of all completers according to the 5-HTTLPR polymorphism

\begin{tabular}{|c|c|c|c|c|c|c|c|c|c|}
\hline & \multicolumn{3}{|c|}{ Total $(n=135)$} & \multicolumn{3}{|c|}{ Female $(n=85)$} & \multicolumn{3}{|l|}{ Male $(n=50)$} \\
\hline & SS & SL \& LL & $p$ & SS & SL \& LL & $p$ & SS & SL \& LL & $p$ \\
\hline $\operatorname{raction}(n[\%])$ & $29[21.5]$ & $106[78.5]$ & & $20[23.5]$ & $65[76.5]$ & & $9[18]$ & $41[82]$ & \\
\hline Age (years) & $48 \pm 10$ & $46 \pm 13$ & $0.32 *$ & $49 \pm 10$ & $44 \pm 13$ & $0.13 *$ & $48 \pm 10$ & $48 \pm 12$ & $0.82 *$ \\
\hline Nicotine use $(n[\%])$ & 4 [13.8] & 19 [17.9] & $0.57^{\dagger}$ & $4[20]$ & 13 [20] & $0.95^{\dagger}$ & $0[0]$ & 6 [14.6] & $0.22^{\dagger}$ \\
\hline $\begin{array}{l}\text { ood } \\
(\mathrm{mmHg})\end{array}$ & 5.4 & $.0 \pm 18.5$ & $9 *$ & $8.2 \pm 13.2$ & $.7 \pm 17.8$ & $9^{*}$ & $2.8 \pm 15.8$ & 19.5 & $0.07 *$ \\
\hline $\begin{array}{l}\text { Diastolic blood } \\
\text { pressure }(\mathrm{mmHg})\end{array}$ & $1 \pm 9.1$ & $88.5 \pm 11.3$ & $2^{*}$ & $4.4 \pm 6.2$ & $9.1 \pm 12.4$ & $*$ & 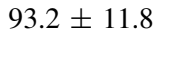 & $7.5 \pm 9.4$ & 0.28 \\
\hline Glucose & $7.0 \pm 2$ & $110.0 \pm 28.8$ & $79 *$ & $06.2 \pm 22.3$ & $4.9 \pm 22.7$ & $0.72 *$ & 0.6 & 5.5 & $0.38 *$ \\
\hline lesterol & $.9 \pm 4$ & $204.4 \pm 39.9$ & $0.29 *$ & $210.0 \pm 46.5$ & $201.4 \pm 3$ & $1 *$ & $222.7 \pm$ & $209.3 \pm$ & $0.38 *$ \\
\hline esterol & $.7 \pm$ & $124.6 \pm 32.2$ & & $.1 \pm$ & $124.6 \pm$ & $4 *$ & $132.9 \pm 31.7$ & $124.6 \pm$ & 0.62 \\
\hline $\begin{array}{l}\text { HDL cholesterol } \\
(\mathrm{mg} / \mathrm{dL})\end{array}$ & $.6 \pm 11.0$ & $48.9 \pm 12.4$ & $9 *$ & $54.6 \pm 10.8$ & $51.7 \pm 13.2$ & $0.19 *$ & $48 \pm 10.5$ & $44.2 \pm 9.4$ & 0.33 \\
\hline $\begin{array}{l}\text { Triacylglycerols } \\
(\mathrm{mg} / \mathrm{dL})\end{array}$ & $9.3 \pm 68.6$ & $153.3 \pm 88.2$ & * & $06.3 \pm 44.3$ & $126.6 \pm 46.0$ & $0 *$ & $186.9 \pm 86.7$ & $197.3 \pm 119.2$ & $0.51 *$ \\
\hline Weight $(\mathrm{kg}) \mathrm{T} 0$ & $19.1 \pm 15.9$ & $125.3 \pm 22.8$ & $0.26^{*}$ & $114.7 \pm 14.9$ & $118.7 \pm 19.5$ & 0. & $128.9 \pm 14.2$ & $135.7 \pm 24$ & 0.50 \\
\hline BMI $\left(\mathrm{kg} / \mathrm{m}^{2}\right)$ T0 & $40.9 \pm 5.1$ & $42.1 \pm 6.4$ & $0.50^{*}$ & $40.9 \pm 5.1$ & $41.9 \pm 6.2$ & $0.65^{*}$ & $40.8 \pm 5.3$ & $42.4 \pm 6.9$ & $0.73 *$ \\
\hline Weight $(\mathrm{kg}) \mathrm{T} 2$ & $99.4 \pm 16.6$ & $101.8 \pm 21.1$ & $0.77 *$ & $97.9 \pm 18.2$ & $97.9 \pm 17.8$ & $0.91 *$ & $102.6 \pm 12.9$ & $108.1 \pm 24.5$ & 0.83 \\
\hline BMI $\left(\mathrm{kg} / \mathrm{m}^{2}\right) \mathrm{T} 2$ & $34.1 \pm 5.8$ & $34.3 \pm 6.5$ & $0.85^{*}$ & $34.9 \pm 6.2$ & $34.6 \pm 5.9$ & $0.87 *$ & $32.5 \pm 4.6$ & $33.8 \pm 7.4$ & $0.95 *$ \\
\hline Weight $(\mathrm{kg}) \mathrm{T} 0-2$ & $-{ }^{-} 19.8 \pm 10.8$ & ${ }^{-} 23.5 \pm 12.1$ & $0.11 *$ & $-16.9 \pm 9.7$ & $-20.8 \pm 9.8$ & $0.07 *$ & $-{ }^{-} 26.2 \pm 10.8$ & $-27.7 \pm 14.2$ & $0.73 *$ \\
\hline BMI $\left(\mathrm{kg} / \mathrm{m}^{2}\right) \mathrm{T} 0-2$ & $-6.7 \pm 3.5$ & $-7.8 \pm 3.8$ & $0.17 *$ & $-6.0 \pm 3.4$ & $-7.3 \pm 3.4$ & $0.10^{*}$ & $-8.3 \pm 3.4$ & $-8.6 \pm 4.3$ & $0.92 *$ \\
\hline Weight (kg) T0-1 & $-18.5 \pm 5.4$ & $-20.3 \pm 5.9$ & $0.12 *$ & $-16.7 \pm 3.1$ & $-18.2 \pm 4.6$ & $0.18^{*}$ & $-22.4 \pm 7.5$ & $-23.7 \pm 6.3$ & $0.52 *$ \\
\hline BMI $\left(\mathrm{kg} / \mathrm{m}^{2}\right) \mathrm{T} 0-1$ & $-6.3 \pm 1.7$ & $-6.8 \pm 1.7$ & $0.14 *$ & $-5.9 \pm 1.0$ & $-6.4 \pm 1.6$ & $0.23 *$ & $-7.1 \pm 2.4$ & $-7.4 \pm 1.8$ & $0.63 *$ \\
\hline Weight (kg) T1-2 & $-1.3 \pm 9.4$ & $-3.1 \pm 8.9$ & $0.30 *$ & $-0.2 \pm 9.4$ & $-2.6 \pm 7.5$ & $0.13 *$ & $-3.8 \pm 9.2$ & $-4.0 \pm 10.7$ & $0.82 *$ \\
\hline BMI $\left(\mathrm{kg} / \mathrm{m}^{2}\right) \mathrm{T} 1-2$ & $-0.4 \pm 3.1$ & $-1.0 \pm 2.9$ & $0.34 *$ & $-0.1 \pm 3.3$ & $-0.9 \pm 2.6$ & $0.15^{*}$ & $-1.2 \pm 2.8$ & $-1.3 \pm 3.3$ & $0.80 *$ \\
\hline
\end{tabular}

T0: start of the program, T1: after weight reduction phase, T2: after weight maintenance phase and end of the program Mean values $\pm \mathrm{SD}$ and $p$ values are given

* Mann-Whitney $U$ test; ${ }^{\dagger} \chi^{2}$ test

BMI in the female $\mathrm{R}+$ group at the end of the program $\left(\mathrm{R}+: \quad 39.1 \pm 6.2 \mathrm{~kg} / \mathrm{m}^{2}, \mathrm{R}-: \quad 34.7 \pm 6.1 \mathrm{~kg} / \mathrm{m}^{2}\right.$, $p=0.09)$. No effect of the combined-risk alleles were observed in men; however, the systolic blood pressure in the male $\mathrm{R}+$ group was increased $(\mathrm{R}+: 157.2 \pm$ $11.5 \mathrm{mmHg}, \mathrm{R}-: \quad 139.4 \pm 17.5 \mathrm{mmHg}, p=0.03)$. No changes in the diastolic pressure was observed. No significant associations of the $\mathrm{R}+$ genotypes on glucose level or blood lipids in both sexes were observed (Table 3 ).

\section{Discussion}

This study has described that genetic modulation of the serotonergic pathway by the 5-HTTLPR and MAOA polymorphisms is associated with a reduced success in weight loss, particularly for women. It was found that female carriers of the SS genotype of the 5-HTTLPR polymorphism had a tendency toward a reduced weight loss for both phases of the study (weight reduction and weight maintenance). Female carriers of the 3R genotype of the MAOA uVNTR polymorphism were found to have a significantly higher BMI at the end of the program, as a result of an impaired weight maintenance phase. Carriers of both risk genotypes had significantly lower weight loss over the course of the whole program and were found to gain weight over the weight maintenance phase compared to other participants.

It has been previously shown that with respect to the 5-HTTLPR polymorphism, there is no association with weight loss (Yamakawa et al. 2005). In this previous study, the 5-HTTLPR polymorphism was analyzed in a Japanese cohort. However, this weight reduction study was conducted in a cohort of Japanese participants who had only moderate obese $\left(26.0 \mathrm{~kg} / \mathrm{m}^{2}\right)$ and a lower overall weight reduction $\left(-1.5 \mathrm{~kg} / \mathrm{m}^{2}\right)$. Furthermore, the study did not 
Table 2 Baseline characteristics and weight loss of all completers according to the MAOA uVNTR polymorphism

\begin{tabular}{|c|c|c|c|c|c|c|c|c|c|}
\hline & \multicolumn{3}{|l|}{ Total $(n=130)$} & \multicolumn{3}{|c|}{ Female $(n=81)$} & \multicolumn{3}{|l|}{ Male $(n=49)$} \\
\hline & $3 \mathrm{R}$ & $3 / 4 R \& 4 / 4 R$ & $p$ & $3 R$ & $3 / 4 \mathrm{R} \& 4 / 4 \mathrm{R}$ & $p$ & $3 R$ & $4 \mathrm{R}$ & $p$ \\
\hline raction $(n[\%])$ & 34 [26.2] & $96[73.8]$ & & 14 [17.3] & $67[82.7]$ & & $20[40.8]$ & $29[59.2]$ & \\
\hline Age (years) & $49 \pm 11$ & $45 \pm 12$ & $0.10 *$ & $48 \pm 9$ & $45 \pm 12$ & $0.35^{*}$ & $50 \pm 13$ & $46 \pm 12$ & $0.25 *$ \\
\hline $\begin{array}{l}\text { Nicotine use } \\
(n[\%])\end{array}$ & $6[17.6]$ & 17 [17.7] & $0.97^{\dagger}$ & $3[21.4]$ & 14 [20.9] & $0.99^{\dagger}$ & $3[6.1]$ & $3[10.4]$ & $0.63^{\dagger}$ \\
\hline $\begin{array}{l}\text { ood } \\
(\mathrm{mmHg})\end{array}$ & $.3 \pm 19.6$ & $8.9 \pm 17.4$ & & $.1 \pm 16.7$ & $7.9 \pm 17.3$ & $*$ & $0 \pm 21.0$ & 7.6 & 0.24 \\
\hline $\begin{array}{l}\mathrm{ood} \\
\mathrm{mmHg})\end{array}$ & $5 \pm 9.5$ & $.7 \pm 11.0$ & & & $87.7 \pm 11.8$ & $75^{*}$ & $.2 \pm 11.4$ & $87.8 \pm 9.0$ & 0.65 \\
\hline Glucose (mg/dL) & $117.8 \pm 33.9$ & $105.5 \pm 23.3$ & $5^{*}$ & $112.5 \pm 26.4$ & $102.1 \pm 19.5$ & $0.22 *$ & $121.5 \pm 38.5$ & $113.9 \pm 29.6$ & 0.64 \\
\hline esterol & $204.1 \pm 42.1$ & $208.6 \pm 39.6$ & $67 *$ & $194.6 \pm 41.8$ & $206.6 \pm 38.1$ & $0.27 *$ & $210.7 \pm 42.0$ & $213.3 \pm 43.2$ & 0.97 \\
\hline $\begin{array}{l}\text { LDL cholesterol } \\
(\mathrm{mg} / \mathrm{dL})\end{array}$ & $2.7 \pm 34.4$ & $128.5 \pm 33$ & & $120.0 \pm 33.3$ & $128.9 \pm 33.0$ & $*$ & $125.0 \pm 36.2$ & $127.4 \pm 33.6$ & 0.82 \\
\hline $\begin{array}{l}\text { HDL cholesterol } \\
(\mathrm{mg} / \mathrm{dL})\end{array}$ & $47.3 \pm 11.2$ & $50.9 \pm 12.5$ & * & $50.1 \pm 12.2$ & $53.6 \pm 12.8$ & $0.18^{*}$ & $45.3 \pm 10.2$ & $44.4 \pm 9.3$ & $0.50 *$ \\
\hline $\begin{array}{l}\text { Triacylglycerols } \\
(\mathrm{mg} / \mathrm{dL})\end{array}$ & $163.3 \pm 99.1$ & $143.1 \pm 80.4$ & $5 *$ & $123.0 \pm 46.8$ & $120.3 \pm 45.1$ & $8^{*}$ & $194.6 \pm 117.7$ & $197.6 \pm 114.8$ & 0.0 \\
\hline Weight $(\mathrm{kg}) \mathrm{T} 0$ & $128 \pm 17.6$ & $123 \pm 23.0$ & $0.08 *$ & $119.6 \pm 15.9$ & $117.7 \pm 19.3$ & $0.62 *$ & $133.8 \pm 16.7$ & $135.3 \pm 26.4$ & $0.74 *$ \\
\hline BMI $\left(\mathrm{kg} / \mathrm{m}^{2}\right)$ T0 & $42.3 \pm 4.6$ & $41.7 \pm 6.7$ & $0.29 *$ & $43.1 \pm 3.6$ & $41.4 \pm 6.4$ & $0.14 *$ & $41.7 \pm 5.2$ & $42.5 \pm 7.5$ & $0.92 *$ \\
\hline Weight $(\mathrm{kg}) \mathrm{T} 2$ & $105.5 \pm 16.9$ & $100.3 \pm 21.4$ & $0.06^{*}$ & $103.3 \pm 17.1$ & $97.0 \pm 18.0$ & $0.15^{*}$ & $107.1 \pm 17.1$ & $107.9 \pm 26.4$ & $0.95 *$ \\
\hline BMI $\left(\mathrm{kg} / \mathrm{m}^{2}\right) \mathrm{T} 2$ & $34.9 \pm 5.3$ & $34.0 \pm 6.6$ & $0.23 *$ & $37.2 \pm 4.7$ & $34.1 \pm 6.1$ & $\mathbf{0 . 0 3} *$ & $33.4 \pm 5.3$ & $33.9 \pm 7.9$ & $0.79 *$ \\
\hline Weight (kg) T0-2 & $-22.5 \pm 12.4$ & $-22.8 \pm 11.9$ & $0.85^{*}$ & $-16.4 \pm 10.9$ & $-20.8 \pm 9.7$ & $0.07 *$ & $-26.8 \pm 11.8$ & $-27.4 \pm 14.9$ & $0.99 *$ \\
\hline BMI $\left(\mathrm{kg} / \mathrm{m}^{2}\right) \mathrm{T} 0-2$ & $-7.3 \pm 3.8$ & $-7.7 \pm 3.8$ & $0.61 *$ & $-5.9 \pm 3.8$ & $-7.3 \pm 3.4$ & $0.10^{*}$ & $-8.3 \pm 3.6$ & $-8.6 \pm 4.5$ & $0.95 *$ \\
\hline Weight (kg) T0-1 & $-21.5 \pm 7.0$ & $-19.5 \pm 5.4$ & $0.14 *$ & $-17.4 \pm 4.8$ & $-18.1 \pm 4.4$ & $0.54 *$ & $-24.3 \pm 7.0$ & $-22.8 \pm 6.2$ & $0.30 *$ \\
\hline BMI $\left(\mathrm{kg} / \mathrm{m}^{2}\right) \mathrm{T} 0-1$ & $-7.0 \pm 2.0$ & $-6.6 \pm 1.6$ & $0.22 *$ & $-6.2 \pm 1.5$ & $-6.3 \pm 1.5$ & $0.96^{*}$ & $-7.6 \pm 2.2$ & $-7.2 \pm 1.8$ & $0.34 *$ \\
\hline Weight (kg) T1-2 & $-1.0 \pm 9.4$ & $-3.3 \pm 8.8$ & $0.26^{*}$ & $+1.0 \pm 10.0$ & $-2.7 \pm 7.6$ & $0.09 *$ & $-2.5 \pm 9.0$ & $-4.6 \pm 11.2$ & $0.75 *$ \\
\hline BMI $\left(\mathrm{kg} / \mathrm{m}^{2}\right) \mathrm{T} 1-2$ & $-0.3 \pm 3.1$ & $-1.1 \pm 2.9$ & $0.22 *$ & $+0.3 \pm 3.5$ & $-1.0 \pm 2.7$ & $0.10^{*}$ & $-0.8 \pm 2.8$ & $-1.4 \pm 3.5$ & $0.72^{*}$ \\
\hline
\end{tabular}

T0: start of the program, T1: after weight reduction phase, T2: after weight maintenance phase and end of the program Mean values \pm SD and $p$ values are given. Significant $p$ values $(p \leq 0.05)$ are standing out in bold

* Mann-Whitney $U$ test; ${ }^{\dagger} \chi^{2}$ test

involve either a weight maintenance phase or a gender specific analysis. This would suggest that due to these factors, the association between the 5-HTTLPR polymorphism and poor weight loss may have been clearly observed.

It has also been shown that genetic modulation of the serotonergic pathway by either 5-HTTLPR and MAOA polymorphisms play a role in the pathogenesis of obesity (Sookoian et al. 2007, 2008; Murphy and Lesch 2008; Need et al. 2006). A higher prevalence of one or both risk alleles is associated with higher BMI values and/or body weight. However, this was based upon a comparison of obese and severely obese individuals, and no lean control groups were studied. In the studies of Sookian et al. (2008), a correlation between the SS genotype of the 5-HTTLPR polymorphism and obesity was observed. However, the cohort studied was of a South American background and had a lower BMI (BMI of $30.0 \pm 0.2 \mathrm{~kg} / \mathrm{m}^{2}$ ) compared to the cohort studied in the results presented here (BMI of $41.7 \pm 6.7 \mathrm{~kg} / \mathrm{m}^{2}$ ). This might explain why we did not observe a higher BMI or body weight in carriers of the studied risk alleles at baseline.

Modulation of the serotonergic pathway has previously been shown to lead to obesity (Yamakawa et al. 2005; Ogden et al. 2012; Cervilla et al. 2006; Lesch et al. 1996). SLC6a4 knock-out mice show reduced locomotor activity, which has been suggested to lead to hypoactivity, diminished energy expenditure and the deposition of energy into adipose tissue (Murphy and Lesch 2008). It has also been shown that modulation of the serotonergic pathway leads to alterations in an individual's psychological state, with pharmaceutical modulation of this pathway being used as a therapeutic approach to the treatment of depression (Arias et al. 2003). The prevalence of both 5-HTTLPR and MAOA polymorphisms have been associated with depression (Cervilla et al. 2006; Nakamura et al. 2000; 
Table 3 Baseline characteristics and weight loss of all completers according to the risk group

\begin{tabular}{|c|c|c|c|c|c|c|}
\hline & \multicolumn{3}{|c|}{ Female $(n=60)$} & \multicolumn{3}{|l|}{ Male $(n=30)$} \\
\hline & $\mathrm{R}+$ & $\mathrm{R}-$ & $p$ & $\mathrm{R}+$ & $\mathrm{R}-$ & $p$ \\
\hline Fraction $(n[\%])$ & $6[10]$ & $54[90]$ & & $5[16.7]$ & $25[83.3]$ & \\
\hline Age (years) & $48 \pm 10$ & $44 \pm 13$ & $0.51 *$ & $50 \pm 12$ & $46 \pm 12$ & $0.49^{*}$ \\
\hline Nicotine use $(n[\%])$ & $3[50]$ & $12[22.2]$ & $0.15^{\dagger}$ & $0[0]$ & $2[8]$ & $0.51^{\dagger}$ \\
\hline Systolic blood pressure $(\mathrm{mmHg})$ & $145.3 \pm 17.1$ & $139.1 \pm 18.0$ & $0.29 *$ & $157.2 \pm 11.5$ & $139.4 \pm 17.5$ & $\mathbf{0 . 0 3}^{*}$ \\
\hline Diastolic blood pressure $(\mathrm{mmHg})$ & $85.2 \pm 5.0$ & $88.9 \pm 12.3$ & $0.47 *$ & $94.4 \pm 10.4$ & $86.9 \pm 8.2$ & $0.15^{*}$ \\
\hline Glucose (mg/dL) & $106.0 \pm 21.5$ & $103.0 \pm 20.8$ & $0.76^{*}$ & $106.2 \pm 10.1$ & $113.8 \pm 30.2$ & $0.61 *$ \\
\hline Total cholesterol (mg/dL) & $211.0 \pm 44.3$ & $204.4 \pm 36.9$ & $0.82 *$ & $222.4 \pm 31.7$ & $210.3 \pm 45.2$ & $0.47 *$ \\
\hline LDL cholesterol (mg/dL) & $138.4 \pm 34.8$ & $126.9 \pm 31.1$ & $0.55 *$ & $124.8 \pm 33.3$ & $123.6 \pm 33.9$ & $0.94 *$ \\
\hline HDL cholesterol(mg/dL) & $49.2 \pm 7.8$ & $52.5 \pm 13.1$ & $0.70 *$ & $43.0 \pm 5.8$ & $42.4 \pm 7.2$ & $0.62 *$ \\
\hline Triacylglycerols (mg/dL) & $116.8 \pm 51.9$ & $124.3 \pm 44.3$ & $0.62 *$ & $233.5 \pm 83.8$ & $208.8 \pm 118$ & $0.39 *$ \\
\hline Weight $(\mathrm{kg}) \mathrm{T} 0$ & $119.3 \pm 17.8$ & $119.2 \pm 20.1$ & $0.89 *$ & $127.3 \pm 18.5$ & $136.6 \pm 27.8$ & $0.62 *$ \\
\hline BMI $\left(\mathrm{kg} / \mathrm{m}^{2}\right)$ T0 & $44.0 \pm 3.1$ & $42.0 \pm 6.5$ & $0.27 *$ & $41.1 \pm 7.2$ & $42.9 \pm 8.0$ & $0.60 *$ \\
\hline Weight $(\mathrm{kg}) \mathrm{T} 2$ & $106.7 \pm 25.0$ & $98.3 \pm 18.5$ & $0.43 *$ & $100.0 \pm 11.7$ & $108.4 \pm 27.8$ & $0.70^{*}$ \\
\hline BMI $\left(\mathrm{kg} / \mathrm{m}^{2}\right) \mathrm{T} 2$ & $39.1 \pm 6.2$ & $34.7 \pm 6.1$ & $0.09 *$ & $32.3 \pm 4.8$ & $34.1 \pm 8.4$ & $0.93 *$ \\
\hline Weight (kg) T0-2 & $-12.6 \pm 8.4$ & $-20.9 \pm 9.8$ & $0.05 *$ & $-27.3 \pm 10.9$ & $-28.2 \pm 15.7$ & $0.93 *$ \\
\hline BMI $\left(\mathrm{kg} / \mathrm{m}^{2}\right) \mathrm{T} 0-2$ & $-4.9 \pm 3.5$ & $-7.4 \pm 3.4$ & $0.09 *$ & $-8.8 \pm 3.6$ & $-8.8 \pm 4.8$ & $0.85^{*}$ \\
\hline Weight (kg) T0-1 & $-16.7 \pm 4.6$ & $-18.4 \pm 4.7$ & $0.61 *$ & $-24.2 \pm 9.3$ & $-23.4 \pm 6.4$ & $0.68 *$ \\
\hline BMI $\left(\mathrm{kg} / \mathrm{m}^{2}\right) \mathrm{T} 0-1$ & $-6.3 \pm 1.5$ & $-6.5 \pm 1.6$ & $0.87 *$ & $-7.8 \pm 3.0$ & $-7.3 \pm 1.8$ & $0.66^{*}$ \\
\hline Weight (kg) T1-2 & $+4.4 \pm 10.1$ & $-2.5 \pm 7.4$ & $0.11 *$ & $-3.0 \pm 7.2$ & $-4.8 \pm 11.5$ & $0.91 *$ \\
\hline BMI $\left(\mathrm{kg} / \mathrm{m}^{2}\right) \mathrm{T} 1-2$ & $+1.4 \pm 3.6$ & $-0.9 \pm 2.6$ & $0.14 *$ & $-1.1 \pm 2.2$ & $-1.5 \pm 3.6$ & $0.93 *$ \\
\hline
\end{tabular}

T0: start of the program, T1: after weight reduction phase, T2: after weight maintenance phase and end of the program

* Mann-Whitney $U$ test; ${ }^{\dagger} \chi^{2}$ test

Mean values $\pm \mathrm{SD}$ and $p$ values are given. Significant $p$ values $(p \leq 0.05)$ are standing out in bold

Fuemmeler et al. 2009). This would suggest that risk genotype carriers in this study may have had a higher level of subclinical depression. It has been shown that depression is a likely contributor to obesity, particularly in women (Scott et al. 2006; Anderson et al. 2007), and this might explain the observed differences in this study between male and female, although no assessment of depression was made. Nevertheless, this conclusion is supported by the studies which have shown that depression is known to affect both weight loss and maintenance, (Elder et al. 2012; Ogden et al. 2012), both of which were shown in our study to be critical in limiting weight loss for women carrying the risk alleles. Furthermore, Fuemmeler et al. (2009) have previously described a relationship between depressive symptoms and larger weight-categorized women. Modulation of the serotonergic pathway by either 5-HTTLPR or MAOA polymorphisms might therefore lead to elevated depression symptoms predominantly in women and ultimately a reduced weight loss and/or maintenance.

Both polymorphisms have also been associated with other personality traits and disorders, such as impulsiveness and impaired self-control, both of which are known to lead to elevated body weight and obesity (Terracciano et al. 2009). This behavior may also be derive from biochemical alterations in areas of the brain responsible for emotional control (Lung et al. 2011; Sookoian et al. 2008; Cervilla et al. 2006; Zalsman et al. 2006; Pluess et al. 2010; Fortier et al. 2010). Subjects carrying the low activity-related $3 \mathrm{R}$ genotype of the MAOA uVNTR polymorphism have been reported to have increased aggressive behavior. This personality trait is known to have direct impact on body weight, especially in women (Louise et al. 2012). Altered and/or heighted personality traits are likely to complicate weight stabilization and maintenance, particularly as theses aspects of weight loss require participants to acknowledge negative experiences and feelings concerning their weight.

It has also been shown that the brain structure of lean individuals are different compared to individuals who has been obese for more than 5 years (Brooks et al. 2013).

Altered brain plasticity, may also play a role in weight stabilization and maintenance, particularly following weight loss, as changes in brain structure will not occur immediately following a short-term weight loss period (Rosas-Vargas et al. 2011; Han et al. 2013). Further studies are required in which both an assessment of a depression and brain structure are made to establish their potential contribution to successfully loss weight. 
Our study, despite the findings, has several limitations. The population had an unequal distribution of males and females (67 vs. 135). Gender bias cannot therefore be excluded with respect to the analysis of entire cohort. As the risk analysis was conducted based upon the gender, the overall sample size was low (Female $\mathrm{R}+: n=6$; $\mathrm{R}-$ : $n=54$; Male $\mathrm{R}+: n=5$; $\mathrm{R}-: n=25$ ). Furthermore, it has been suggested that the 5-HTLLPR polymorphism also exists in a tri-allelic form with the long allele consisting of a $\mathrm{L}_{\mathrm{A}}$ and an $\mathrm{L}_{\mathrm{G}}$ subgroups. The latter having a similar transcriptional activity as the short allele (Nakamura et al. 2000). It is unclear whether the presence of this 5-HTLLPR polymorphism affects our results. Another limitation of our study is that the results would not hold for statistical significance when they were controlled for multiple testing. Further research needs to be done to replicate the results.

Pathogenesis of obesity is complex in which a combination of both genetic and environmental factors lead to an individual becoming overweight and subsequently having problems with either weight reduction or maintenance (Elder et al. 2012). The findings of this study supports the need for genetic analysis of obese individuals prior to weight reduction, as to help identify those who are at high risk of unsuccessfully weight loss. For such individuals, a personalized strategy can then be used, involving intensified psychotherapy and surgery, to help improve overall weight loss.

Acknowledgments This work was supported by a Grant of European Foundation of the Study of Diabetes (EFSD 2012/2013) (G.R., C.W.) and of ERC (AdipoDif C.W.). All experiments comply with the current law of Germany. The ethics committee at the University of Heidelberg approved the study and written approval was given by all participants prior to their inclusion in the study.

\section{References}

Anderson SE, Cohen P, Naumova EN, Jacques PF, Must A (2007) Adolescent obesity and risk for subsequent major depressive disorder and anxiety disorder: prospective evidence. Psychosom Med 69(8):740-747. doi:10.1097/PSY.0b013e31815580b4

Arias B, Catalan R, Gasto C, Gutierrez B, Fananas L (2003) 5-HTTLPR polymorphism of the serotonin transporter gene predicts non-remission in major depression patients treated with citalopram in a 12-weeks follow up study. J Clin Psychopharmacol 23(6):563-567. doi:10.1097/01.jcp.0000095350.32154.73

Beach SR, Brody GH, Gunter TD, Packer H, Wernett P, Philibert RA (2010) Child maltreatment moderates the association of MAOA with symptoms of depression and antisocial personality disorder. J Fam Psychol 24(1):12-20. doi:10.1037/a0018074

Bombelli M, Facchetti R, Sega R, Carugo S, Fodri D, Brambilla G, Giannattasio C, Grassi G, Mancia G (2011) Impact of body mass index and waist circumference on the long-term risk of diabetes mellitus, hypertension, and cardiac organ damage. Hypertension 58(6):1029-1035. doi:10.1161/HYPERTENSIONAHA.111. 175125
Bray GA (2006) Obesity: the disease. J Med Chem 49(14): 4001-4007. doi:10.1021/jm0680124

Brooks SJ, Benedict C, Burgos J, Kempton MJ, Kullberg J, Nordenskjold R, Kilander L, Nylander R, Larsson EM, Johansson L, Ahlstrom H, Lind L, Schioth HB (2013) Late-life obesity is associated with smaller global and regional gray matter volumes: a voxel-based morphometric study. Int J Obes (Lond) 37(2):230-236. doi:10.1038/ijo.2012.13

Cervilla JA, Rivera M, Molina E, Torres-Gonzalez F, Bellon JA, Moreno B, de Dios Luna J, Lorente JA, de Diego-Otero Y, King M, Nazareth I, Gutierrez B (2006) The 5-HTTLPR s/s genotype at the serotonin transporter gene (SLC6A4) increases the risk for depression in a large cohort of primary care attendees: the PREDICT-gene study. Am J Med Genet Part B Neuropsychiatr Genet 141B(8):912-917. doi:10.1002/ajmg.b.30455

Collier DA, Stober G, Li T, Heils A, Catalano M, Di Bella D, Arranz MJ, Murray RM, Vallada HP, Bengel D, Muller CR, Roberts GW, Smeraldi E, Kirov G, Sham P, Lesch KP (1996) A novel functional polymorphism within the promoter of the serotonin transporter gene: possible role in susceptibility to affective disorders. Mol Psychiatry 1(6):453-460

Deckert J, Catalano M, Syagailo YV, Bosi M, Okladnova O, Di Bella D, Nothen MM, Maffei P, Franke P, Fritze J, Maier W, Propping P, Beckmann H, Bellodi L, Lesch KP (1999) Excess of high activity monoamine oxidase A gene promoter alleles in female patients with panic disorder. Hum Mol Genet 8(4):621-624

Elder CR, Gullion CM, Funk KL, Debar LL, Lindberg NM, Stevens VJ (2012) Impact of sleep, screen time, depression and stress on weight change in the intensive weight loss phase of the LIFE study. Int J Obes (Lond) 36(1):86-92. doi:10.1038/ijo.2011.60

Fortier E, Noreau A, Lepore F, Boivin M, Perusse D, Rouleau GA, Beauregard M (2010) Early impact of 5-HTTLPR polymorphism on the neural correlates of sadness. Neurosci Lett 485(3):261265. doi:10.1016/j.neulet.2010.09.026

Fuemmeler BF, Agurs-Collins T, McClernon FJ, Kollins SH, Garrett ME, Ashley-Koch AE (2009) Interactions between genotype and depressive symptoms on obesity. Behav Genet 39(3):296-305. doi:10.1007/s10519-009-9266-Z

Han JC, Thurm A, Golden Williams C, Joseph LA, Zein WM, Brooks BP, Butman JA, Brady SM, Fuhr SR, Hicks MD, Huey AE, Hanish AE, Danley KM, Raygada MJ, Rennert OM, Martinowich K, Sharp SJ, Tsao JW, Swedo SE (2013) Association of brain-derived neurotrophic factor (BDNF) haploinsufficiency with lower adaptive behaviour and reduced cognitive functioning in WAGR/11p13 deletion syndrome. Cortex. doi:10.1016/ j.cortex.2013.02.009

Heils A, Teufel A, Petri S, Stober G, Riederer P, Bengel D, Lesch KP (1996) Allelic variation of human serotonin transporter gene expression. J Neurochem 66(6):2621-2624

Hranilovic D, Stefulj J, Schwab S, Borrmann-Hassenbach M, Albus M, Jernej B, Wildenauer D (2004) Serotonin transporter promoter and intron 2 polymorphisms: relationship between allelic variants and gene expression. Biol Psychiatry 55(11): 1090-1094. doi:10.1016/j.biopsych.2004.01.029

Iordanidou M, Tavridou A, Petridis I, Arvanitidis KI, Christakidis D, Vargemezis V, Manolopoulos VG (2010) The serotonin transporter promoter polymorphism (5-HTTLPR) is associated with type 2 diabetes. Clin Chim Acta 411(3-4):167-171. doi:10.1016/ j.cca.2009.10.022

Kopelman PG (2000) Obesity as a medical problem. Nature 404(6778):635-643. doi:10.1038/35007508

Kuikka JT, Tammela L, Karhunen L, Rissanen A, Bergstrom KA, Naukkarinen H, Vanninen E, Karhu J, Lappalainen R, RepoTiihonen E, Tiihonen J, Uusitupa M (2001) Reduced serotonin transporter binding in binge eating women. Psychopharmacology 155(3):310-314 
Leibowitz SF, Alexander JT (1998) Hypothalamic serotonin in control of eating behavior, meal size, and body weight. Biol Psychiatry 44(9):851-864

Lesch KP, Wolozin BL, Estler HC, Murphy DL, Riederer P (1993) Isolation of a cDNA encoding the human brain serotonin transporter. J Neural Transm Gen Sect 91(1):67-72

Lesch KP, Balling U, Gross J, Strauss K, Wolozin BL, Murphy DL, Riederer P (1994) Organization of the human serotonin transporter gene. J Neural Transm Gen Sect 95(2):157-162

Lesch KP, Bengel D, Heils A, Sabol SZ, Greenberg BD, Petri S, Benjamin J, Muller CR, Hamer DH, Murphy DL (1996) Association of anxiety-related traits with a polymorphism in the serotonin transporter gene regulatory region. Science 274(5292):1527-1531

Louise S, Warrington NM, McCaskie PA, Oddy WH, Zubrick SR, Hands B, Mori TA, Briollais L, Silburn S, Palmer LJ, Mattes E, Beilin LJ (2012) Associations between aggressive behaviour scores and cardiovascular risk factors in childhood. Pediatr Obes 7(4):319-328. doi:10.1111/j.2047-6310.2012.00047.x

Lung FW, Tzeng DS, Huang MF, Lee MB (2011) Association of the MAOA promoter uVNTR polymorphism with suicide attempts in patients with major depressive disorder. BMC Med Genet 12:74. doi:10.1186/1471-2350-12-74

Monteleone P, Santonastaso P, Mauri M, Bellodi L, Erzegovesi S, Fuschino A, Favaro A, Rotondo A, Castaldo E, Maj M (2006) Investigation of the serotonin transporter regulatory region polymorphism in bulimia nervosa: relationships to harm avoidance, nutritional parameters, and psychiatric comorbidity. Psychosom Med 68(1):99-103. doi:10.1097/01.psy.0000195746. 52074.63

Murphy DL, Lesch KP (2008) Targeting the murine serotonin transporter: insights into human neurobiology. Nat Rev Neurosci 9(2):85-96. doi:10.1038/nrn2284

Nakamura M, Ueno S, Sano A, Tanabe H (2000) The human serotonin transporter gene linked polymorphism (5-HTTLPR) shows ten novel allelic variants. Mol Psychiatry 5(1):32-38

Need AC, Ahmadi KR, Spector TD, Goldstein DB (2006) Obesity is associated with genetic variants that alter dopamine availability. Ann Hum Genet 70(Pt 3):293-303. doi:10.1111/j.1529-8817. 2005.00228.x

Ogden CL, Yanovski SZ, Carroll MD, Flegal KM (2007) The epidemiology of obesity. Gastroenterology 132(6):2087-2102. doi:10.1053/j.gastro.2007.03.052

Ogden LG, Stroebele N, Wyatt HR, Catenacci VA, Peters JC, Stuht J, Wing RR, Hill JO (2012) Cluster analysis of the National Weight Control Registry to identify distinct subgroups maintaining successful weight loss. Obesity (Silver Spring). doi:10.1038/ oby.2012.79

Pluess M, Belsky J, Way BM, Taylor SE (2010) 5-HTTLPR moderates effects of current life events on neuroticism: differential susceptibility to environmental influences. Prog Neuropsychopharmacol Biol Psychiatry 34(6):1070-1074. doi:10.1016/ j.pnpbp.2010.05.028

Rankinen T, Zuberi A, Chagnon YC, Weisnagel SJ, Argyropoulos G, Walts B, Perusse L, Bouchard C (2006) The human obesity gene map: the 2005 update. Obesity 14(4):529-644

Rosas-Vargas H, Martinez-Ezquerro JD, Bienvenu T (2011) Brainderived neurotrophic factor, food intake regulation, and obesity.
Arch Med Res 42(6):482-494. doi:10.1016/j.arcmed.2011. 09.005

Sabol SZ, Hu S, Hamer D (1998) A functional polymorphism in the monoamine oxidase A gene promoter. Hum Genet 103(3): 273-279

Scott KM, Oakley Browne MA, McGee MA, Wells JE (2006) Mental-physical comorbidity in Te Rau Hinengaro: the New Zealand Mental Health Survey. Aust N Z J Psychiatry 40(10):882-888. doi:10.1111/j.1440-1614.2006.01907.x

Smeraldi E, Serretti A, Artioli P, Lorenzi C, Catalano M (2006) Serotonin transporter gene-linked polymorphic region: possible pharmacogenetic implications of rare variants. Psychiatr Genet 16(4):153-158. doi:10.1097/01.ypg.0000218611.53064.a0

Sookoian S, Gemma C, Garcia SI, Gianotti TF, Dieuzeide G, Roussos A, Tonietti M, Trifone L, Kanevsky D, Gonzalez CD, Pirola CJ (2007) Short allele of serotonin transporter gene promoter is a risk factor for obesity in adolescents. Obesity (Silver Spring) 15(2):271-276. doi:10.1038/oby.2007.519

Sookoian S, Gianotti TF, Gemma C, Burgueno A, Pirola CJ (2008) Contribution of the functional 5-HTTLPR variant of the SLC6A4 gene to obesity risk in male adults. Obesity (Silver Spring) 16(2):488-491. doi:10.1038/oby.2007.64

Tauscher J, Pirker W, Willeit M, de Zwaan M, Bailer U, Neumeister A, Asenbaum S, Lennkh C, Praschak-Rieder N, Brucke T, Kasper S (2001) [123I] beta-CIT and single photon emission computed tomography reveal reduced brain serotonin transporter availability in bulimia nervosa. Biol Psychiatry 49(4):326-332

Terracciano A, Sutin AR, McCrae RR, Deiana B, Ferrucci L, Schlessinger D, Uda M, Costa PT Jr (2009) Facets of personality linked to underweight and overweight. Psychosom Med 71(6):682-689. doi:10.1097/PSY.0b013e3181a2925b

Winkler JK, Woehning A, Schultz JH, Brune M, Beaton N, Challa TD, Minkova S, Roeder E, Nawroth PP, Friederich HC, Wolfrum C, Rudofsky G (2012) TaqIA polymorphism in dopamine D2 receptor gene complicates weight maintenance in younger obese patients. Nutrition. doi:10.1016/j.nut.2011.12.018

Woehning A, Schultz JH, Roeder E, Moeltner A, Isermann B, Nawroth PP, Wolfrum C, Rudofsky G (2012) The A-allele of the common FTO gene variant rs9939609 complicates weight maintenance in severe obese patients. Int $\mathrm{J}$ Obes (Lond). doi: 10.1038/ijo.2012.14

Yamakawa M, Fukushima A, Sakuma K, Yanagisawa Y, Kagawa Y (2005) Serotonin transporter polymorphisms affect human blood glucose control. Biochem Biophys Res Commun 334(4): 1165-1171. doi:10.1016/j.bbrc.2005.07.022

York DA, Rossner S, Caterson I, Chen CM, James WP, Kumanyika S, Martorell R, Vorster HH (2004) Prevention Conference VII: obesity, a worldwide epidemic related to heart disease and stroke: group I: worldwide demographics of obesity. Circulation 110(18):e463-e470. doi:10.1161/01.CIR.0000140125.26161.49

Zalsman G, Huang YY, Oquendo MA, Burke AK, Hu XZ, Brent DA, Ellis SP, Goldman D, Mann JJ (2006) Association of a triallelic serotonin transporter gene promoter region (5-HTTLPR) polymorphism with stressful life events and severity of depression. Am J Psychiatry 163(9):1588-1593. doi:10.1176/appi.ajp.163.9. 1588 